DOI 10.18551/rjoas.2019-12.12

\title{
THE IMPACT OF TOURISM GROWTH ON INCLUSIVE ECONOMIC GROWTH AND CHANGES IN ECONOMIC STRUCTURE IN BALI PROVINCE, INDONESIA
}

\author{
Utama Made Suyana* \\ Faculty of Economics and Business, University of Udayana, Bali, Indonesia
}

Raharja Made Agung*

Faculty of Mathematics and Natural Sciences, University of Udayana, Bali, Indonesia

\author{
*E-mail: suyanautama@unud.ac.id
}

\begin{abstract}
Almost all countries or regions today have developed the tourism sector has been in its development program. Tourism has also been shown to be able to increase economic growth. But until now it is still questionable whether the development of the tourism sector is able to provide inclusive or quality economic growth, namely economic growth accompanied by reducing unemployment, poverty, and income inequality. This study aims to analyze the effect of tourism development on inclusive economic growth and changes in economic structure in Bali Province. The data used were obtained from the secondary sector, namely the Central Statistics Agency of Bali Province in the period 1980-2018. The analysis technique used was the causality method using Structural Equation Model (SEM) with Partial Least Square (PLS) software. The results showed that the development of tourism had a positive effect on inclusive economic growth and changes in economic structure in the Province of Bali, inclusive economic growth had a positive effect on changes in economic structure, and the development of tourism had an indirect effect on changes in economic structure in the Province of Bali through inclusive economic growth.
\end{abstract}

\section{KEY WORDS}

Tourism development, inclusive growth, changes, economic structure.

In the Province of Bali the tourism sector since 1969 was officially used as the leading sector in the three pillars of regional development in addition to the other pillar sectors, namely the agricultural sector and the small industrial sector. By relying on the potential of the natural beauty and culture of tourist visits, although slightly fluctuating, but has a tendency to increase every year accompanied by the construction of tourism facilities and infrastructure. Data from the Central Bureau of Statistics of the Province of Bali shows that during the period 1980-2018 foreign tourist visits increased by an average of 11.04 percent per year, from 147,000 people in 1980 to 6,060,500 people in 2018. Domestic tourists increased from 198,000 people in 1980 to 45.496,000 people in 2018 or with an average annual increase of 11.23 percent. The added value generated by the trade, hotel and restaurant sector which is calculated based on constant prices in 2010 also increased. In 1980 the contribution of the added value of this sector amounted to Rp 1.68 trillion rupiah, and in 2018 it increased to Rp 45.50 trillion, or with an average increase of 9.51 percent per year during the period 1980-2018.

This study aims to determine the impact of tourism development on inclusive economic growth and changes in economic structure in the Province of Bali. Some writings on the impact of tourism development on economic growth and social welfare can be seen in the writings by Cohen (1984), Spelane (1983), Bull (1991), Pey and Lin (1993), Lundberg et al. (1997), Archer (2000), Martin et al. (2004), and Ave (2006).

With the development of tourism which is indicated to increase foreign and domestic tourist visits as well as revenue from the trade, hotel and restaurant sector, there is an inclusive economic growth, namely increasing per capita income, decreasing unemployment and poverty levels, and decreasing income inequality. The development of tourism can also 
improve the welfare of the community which is indicated to increase the purchasing power of the community, increasing life expectancy and the average length of schooling.

The development of the tourism sector in addition to having a positive influence on the economy can also have a negative influence on the socioeconomic, socio-cultural, and environment, as stated by Inskeep (1991: 86), Bull (1991: 134), Nowak (2004), and Pitana (2005: 109). The negative influence of the development of the tourism sector from the socioeconomic aspect is the high prices in tourist destinations so that people's purchasing power decreases. Another socioeconomic influence is the occurrence of economic leakage (economic leakage) if investment for development in the tourism sector and its supporting facilities and the required inputs are imported from many countries (foreign countries and outside regions).

This research is expected to be able to find the development of tourism towards inclusive economic growth and changes in economic structure in the Province of Bali as an input for planning tourism development in the future.

\section{METHODS OF RESEARCH}

To examine the effect of tourism development on inclusive economic growth and changes in economic structure, this study uses a quantitative research design with a tiered causality relationship using the least square partial data processing software (PLS). This research is based on a framework and conceptual framework that draws on previous theory and research on the development of tourism, inclusive economic growth and changes in economic structure. The relationship between variables in this study is shown in Figure 3.1.

Research data relating to the development of tourism, inclusive economic growth and changes in economic structure in the Province of Bali during 1980-2018 are secondary data with a ratio scale obtained from the Central Statistics Agency of the Province of Bali.

Operational research variables are defined as follows. Foreign tourists are tourists who are not native to Indonesia who travel to parts of Indonesia, in this case to Bali for the purpose of satisfying physical and spiritual needs, but not to work in the span of one day (24 hours) and less than a year (BPS BPS Bali, 2019). Domestic tourists or domestic tourists are Indonesian residents, other than residents who have a Balinese identity card, who travels in Bali for the purpose of satisfying physical and spiritual needs, but not to work within a span of one day (24 hours) and less from a year (BPS Bali Province, 2019). The GRDP of the trade, hotel and restaurant sub-sector is calculated based on the value added or net product value of trade activities, restaurants, and businesses providing accommodation to the public in the form of accommodation for a relatively short period of time (BPS Bali Province, 2019).

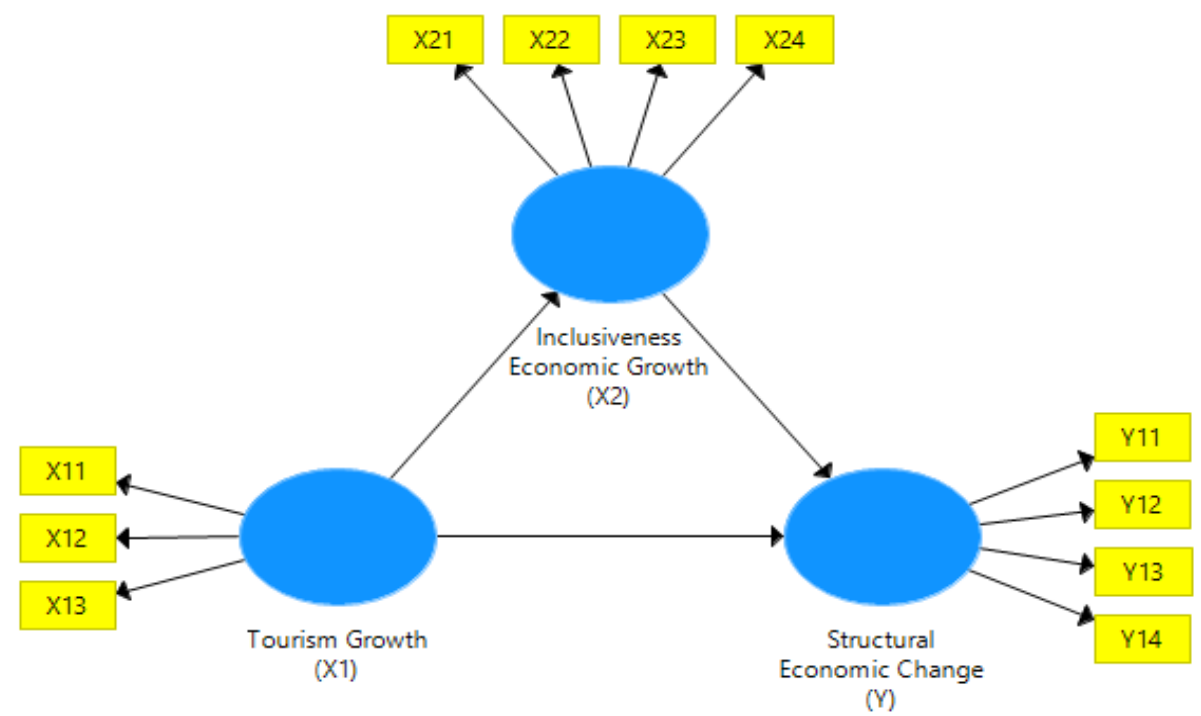

Figure 1 - Research Conceptual Framework 
The variables that are incorporated in the construct of inclusive economic growth are the rate of economic growth, the percentage of employment, the percentage of the population above the poverty line, and the level of equity of income distribution (Birdsall, 2007). Variables that are incorporated in the structure of the economic structure are the structure of production, the structure of labor, the structure of capital, and patterns of public consumption expenditure. The production structure is reflected by the ratio of agricultural sector production to nonfarm sector production. The structure of labor is a decrease in the ratio of absorption of labor to the agricultural sector to non-agriculture. The capital structure can be seen from the percentage of gross domestic fixed capital formation (GDFCF) of the total GRDP. Community consumption patterns are reflected by the percentage of household expenditure for non-food items (Sukirno, 2001) and (Tambunan, 2003).

To analyze the data obtained used descriptive statistical methods and Structural Equation Modeling (SEM) with the help of Smart PLS (Partial Least Square) software. The results of data processing with PLS are then carried out in two stages of evaluation. The first is done through an evaluation of the outer model and the inner model. The first step is evaluating the measurement model or outer model which is carried out in accordance with the relationship between the indicator and its construct. In PLS it is known that there are two types of relationships between indicators and constructs, namely the reflective model and the formative model. In this study all constructs use the reflective model. Therefore, the evaluation of the measurement is done in several ways, namely: 1) Convergent Validity (CV) on the reflective indicator that is by looking at the correlation or loading factor between the measured variable and the latent variable. A tolerated value of at least 0.50 is considered sufficient (Chin, 1998). 2) Construck Reliability and Validity, generally used for reflective indicators measured by internal consistency $(\rho c)$, cronbach alpha and variance extracted (AVE). Values of $\rho c$ and cronbach alpha are required to be greater than 0.70 , a minimum AVE value of 0.50 . 3) Discrimanant Validity (DV) on reflective indicators, namely by looking at (i) crossloading of the construct or latent, (ii) and (ii) SQAVE (square root of average variance extracted).

The second evaluation is done by looking at the validity of the inner model. In PLS the inner model is also called the inner relation which describes the relationship between latent variables based on the substance of the theory. There are three types of evaluations that are important to do on the inner model, namely (1) evaluation of goodness of fit, (2) test of direct influence, and (3) test of indirect effect or mediation. Before evaluating the inner model, a structural equation system is first made. Based on Figure 3.1, a structural equation system is made as follows:

$$
\begin{aligned}
& \begin{array}{r}
\text { Relationship between } X_{1} \text { toward } X_{2} \\
X_{2}=\beta_{1} X_{1}+\varepsilon_{1}
\end{array} \\
& \text { Relationship between } X_{1} \text { and } Y_{1} \text {, toward } Y_{2} \\
& Y=\beta_{2} X_{1}+\beta_{3} X_{2}+\varepsilon_{2}
\end{aligned}
$$

Where: $\mathrm{X} 1$ is the tourism growth; $\mathrm{X} 2$ is inclusive economic growth; $\mathrm{Y}$ is a change in economic structure; $\beta_{1}, \beta_{2}$, and $\beta_{3}$ is path coefficient; $e_{1}, e_{2} \ldots e_{3}$ is error.

\section{RESULTS AND DISCUSSION}

Description of research variables. In this study the indicators of tourism development are foreign or foreign tourist visits, abbreviated as foreign tourists, domestic tourist visits abbreviated as wisdom, as well as added value from the trade, hotel and restaurant sectors. The development of these indicators can be seen in Figure 2. 


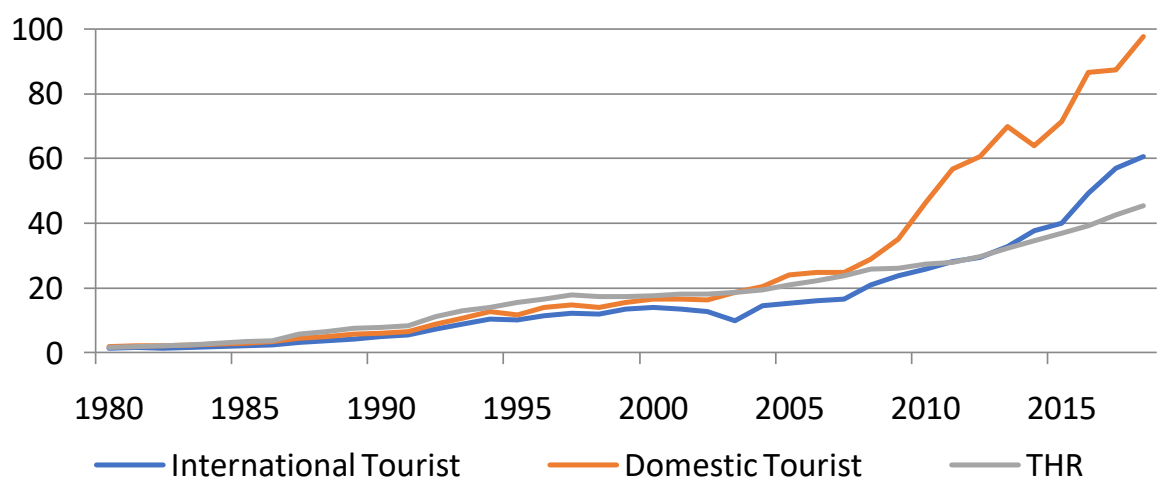

Figure 2 - International Tourist Visits, Domestic Tourist Visits, and Value Added from the Trade, Hotel and Restaurant Sectors in Bali Province, 1980-2018 (International and Domestic in hundreds of thousands of persons, Added Value of Trade, Hotel, and Restaurant Sector (THR) in Trillion Rupiahs)

Based on Figure 2 it can be explained that foreign tourist arrivals, domestic tourist visits abbreviated as wisdom, as well as added value from the trade, hotel and restaurant sector fluctuate somewhat, but experience an increasing trend. Foreign or foreign tourist arrivals increased by an average of 11.04 percent per year during the period 1980-2018, from 147,000 people in 1980 to $6,060,500$ people in 2018. Domestic tourists increased from 198,000 people in 1980 to $45,496.000$ people in 2018 or with an average annual increase of 11.23 percent. The added value generated by the trade, hotel and restaurant sector which is calculated based on constant prices in 2010 also increased. In 1980 the contribution of value added to this sector amounted to Rp 1.68 trillion rupiah, while in 2018 it increased to $\mathrm{Rp}$ 45.50 trillion, or with an average increase of 9.51 percent per year during the period 1980 2018.

Indicators of inclusive economic growth in this study are the rate of economic growth, income evenness index, labor absorption, and non-poor population. The income equity index in this study is calculated from 1 minus the Gini Ratio, labor absorption is calculated from 100 minus the unemployment rate, and the non-poor population is obtained from 100 minus the poverty rate in Bali Province during 1980-2018. The rate of economic growth, the rate unemployment and poverty levels are presented in Figure 3.

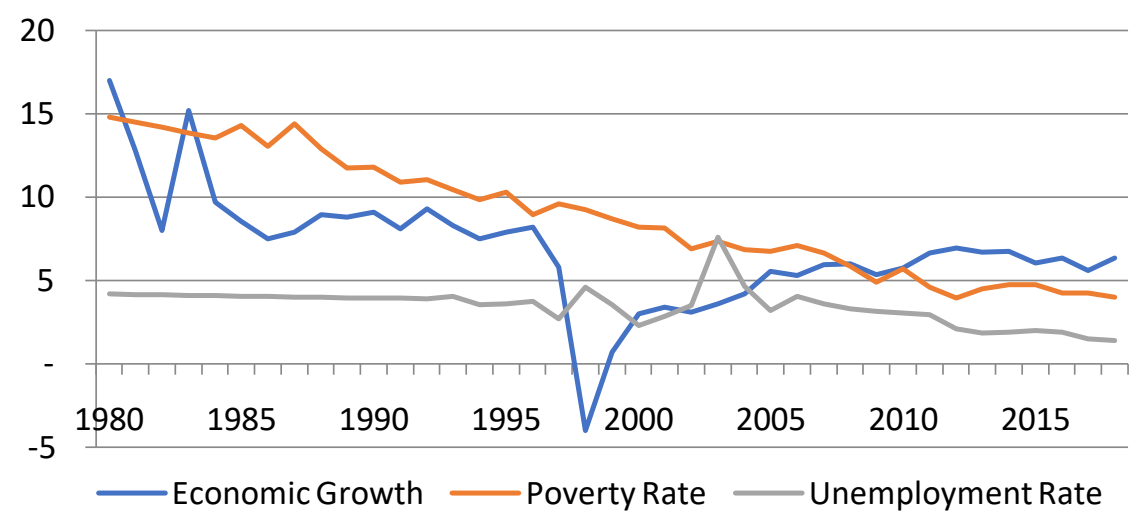

Figure 3 - Economic growth rate, poverty rate, and unemployment rate in the Province of Bali, 1980-2018 (\%)

Based on Figure 3 it can be seen that the rate of economic growth, the unemployment rate and the poverty rate during 1980-2018 fluctuated slightly, but had a declining trend. The rate of economic growth in Bali Province experienced a contraction or negative of -4.00 
percent in 1998 when there was an economic and political crisis in Indonesia. In 1980 the poverty level in Bali Province amounted to 14.79 percent had a declining trend, in 2018 it became 4.01 percent. The unemployment rate in the Province of Bali in 1980 was only 4.18 percent, which was lower than the theoretical recommendation of 5 percent and continued to decline 1.37 percent in 2018. The unemployment rate had experienced a quite high increase in 2003 after the Bali Bombing I and II tragedy occurred in Kuta.

Other indicators of inclusive economic growth are decreasing income inequality or increasing income equality. In this study the Gini Ratio number is used. The smaller the Gini Ratio shows the more evenly distributed income distribution in an area, conversely the greater the Gini Ratio shows the unequal distribution of income in an area. The Gini Ratio in the Province of Bali from 1980 to 2018 is presented in Figure 4.

Based on Figure 4 it can be explained that the Bali Province Gini Ratio from 1980-2018 is highly fluctuating every year, but has a tendency to increase. In other words, during this period income inequality increased. The lowest level of income inequality occurred in 1982 and 1984, namely with the number 0.19 , while the highest occurred in 2012 , amounting to 0.42 or with the category of "quite lame". Todaro (2000) says that inequality increases if the modern sector experiences rapid growth that is far greater than the traditional sector which is relatively stagnant and constant. In addition, government revenue and expenditure transfer policies which are not implemented due to low government revenues, have led to a more unequal distribution of income.

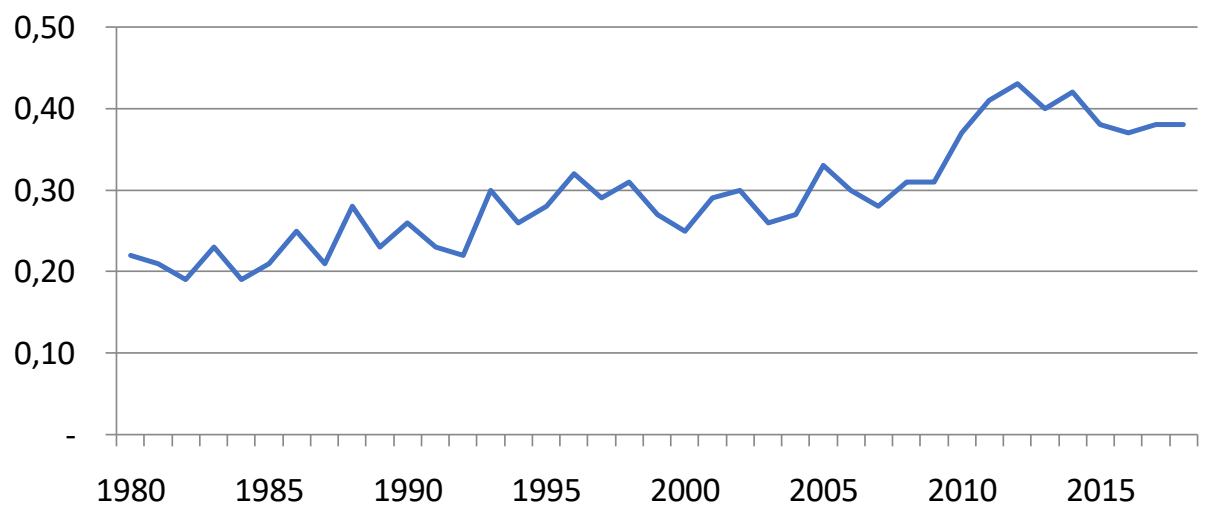

Figure 4 - Gini Ratio in Bali Province, 1980-2018

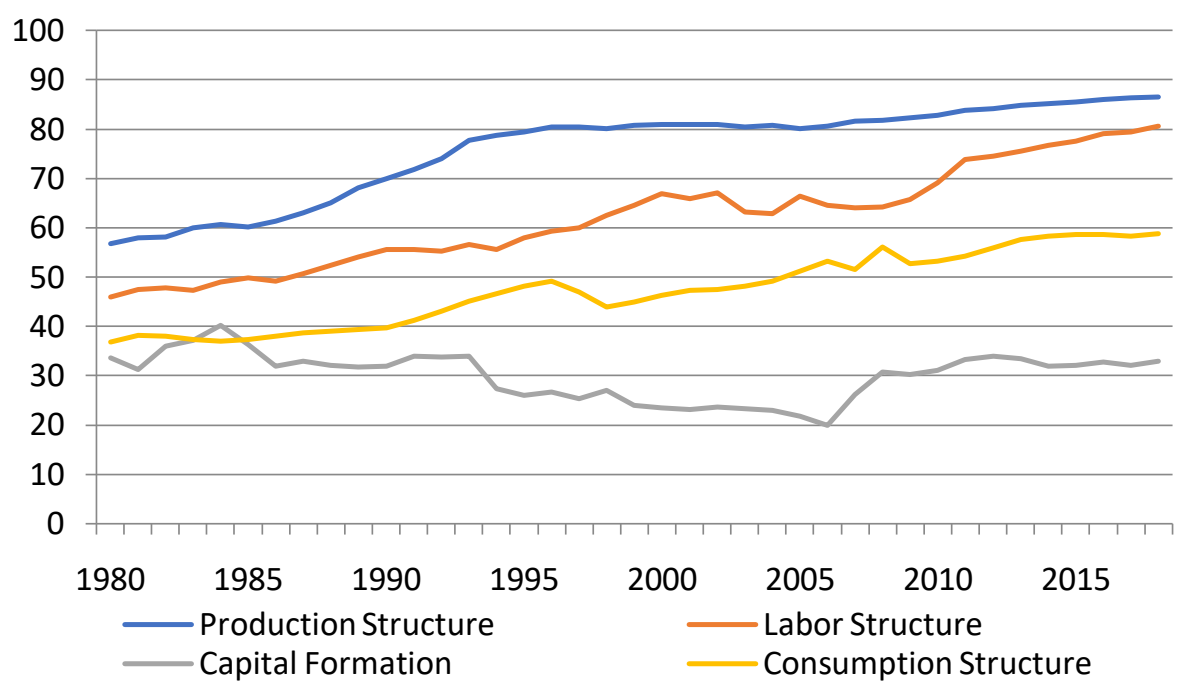

Figure 5 - Change in Economic Structure in the Province of Bali, 1980-2018 
Indicators of changes in economic structure in this study are changes in the structure of production, namely the contribution of the non-agricultural sector to the formation of GRDP, changes in the structure of labor, namely changes in the proportion of non-agricultural sector labor absorption to total employment, changes in the proportion of gross fixed capital formation to GRDP, and the proportion of non-food expenditure to total household expenditure in Bali Province. Theoretically, it is necessary to change the structure of the economy from traditional to modern. The more modern economic structure shows the increasing productivity of labor and capital, as well as increasing the level of welfare of the community, because the proportion of non-food expenditure such as for education, health, and old age insurance. Data on changes in economic structure in the Province of Bali during 1980-2018 is presented in Figure 5.

Based on Figure 5 it can be seen that the production structure, labor, and consumption structure, although fluctuating, have a tendency to increase from 1980-2018. This identifies that productivity and the level of welfare of the people in the Province of Bali during this period increased. On the other hand capital structure, although fluctuating, has a tendency to stagnate. In the early 1980s there was an increase in investment with the start of construction of tourism facilities and infrastructure in the Nusa Dua Region, then investment was rather lethargic after the financial crisis in 1998 until the tragedy of the Bali Bombings I and II. After 2005 investment rose again with the construction of tourism infrastructure in the South Bali region as well as in other regions, such as in Klungkung Regency, particularly in the Nusa Penida District.

Structural Equation Model. Overall, a full model of the effect of tourism development on inclusive economic growth and changes in economic structure in the Province of Bali is presented in Figure 1. The PLS output results on convergent validity are presented in Figure 6. Y13, the investment structure with a loading factor of 0.140 less than 0.50 as required. Therefore the indicator is excluded from the model.

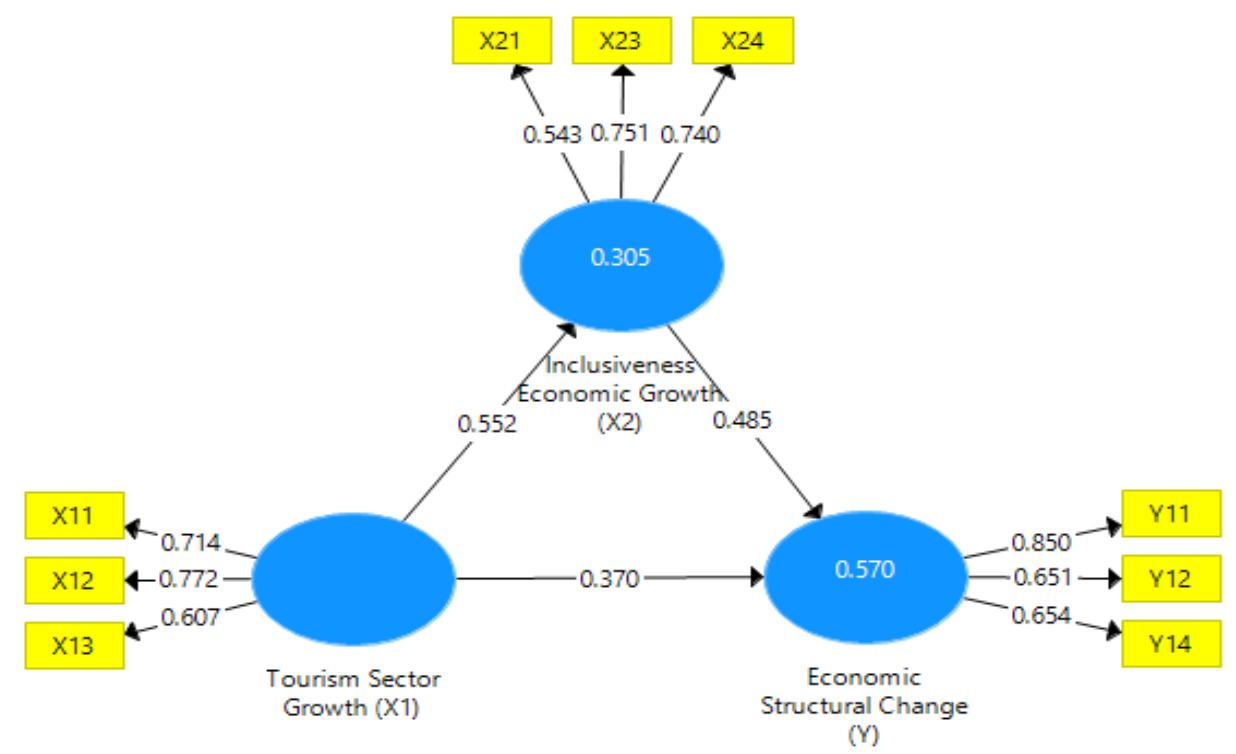

Figure 6 - Structural Models the Effect of Tourism Development on Inclusive Economic Growth and Changes in Economic Structure in the Province of Bali (After revision)

Based on Figure 1 it can be seen that all loading factors of each construct have a loading factor value greater than 0.50 , so the structural model is declared valid. To know the validity of a construct can also be seen from the discriminant validity. Discriminant validity in reflective indicators is to look at the indicator crossloading of its construct or latency. The results of the processed data show that in terms of discriminant validity, all the constructs of this study were declared valid, because all indicators have a crossloading value on each construct greater than the other constructs. 
Direct and indirect effects. Based on Table 1 it can be seen that the development of tourism has a positive and significant effect on economic growth with a $P$. Value of 0,000 , and on changes in economic structure with a $P$. Value of 0.027 . Inclusive economic growth also has a positive and significant effect on changes in economic structure with a $P$. value of 0.011 .

Table 1 - Direct Effect of Research Variables The Effect of Tourism Development on Inclusive Economic Growth and Changes in Economic Structure in the Province of Bali, 1980-2018

\begin{tabular}{ccccc}
\hline Variable Relation & Original sample & Deviation Standard & t- Statistic & P-Value \\
\hline$X 1 \rightarrow$ X2 & 0,552 & 0,111 & 4,971 & 0,000 \\
$X 1 \rightarrow Y$ & 0,370 & 0,167 & 2,212 & 0,027 \\
$X 2 \rightarrow Y$ & 0,485 & 0,189 & 2,563 & 0,011 \\
\hline
\end{tabular}

Source: Research Result.

Note: $X 1=$ Tourism development; $X 2$ = Inclusiveness economic growth; $X 3=$ Structural economic change .

Based on the results of processed data with PLS the indirect effect of a variable or research construct is presented in Table 2. Based on Table 2 it can be seen that the indirect effect of tourism development on changes in economic structure through inclusive economic growth has a coefficient of 0.434 and $P$. Value of 0.000 . This means that increasing the development of tourism with indicators of foreign and domestic tourist visits and the added value of the hotel and restaurant trade sector can increase inclusive economic growth. Furthermore, increasing inclusive economic growth causes changes in economic structure.

Table 2 - Indirect Effects of Tourism Development on Changes in Economic Structure through Inclusive Economic Growth in the Province of Bali, 1980-2018

\begin{tabular}{cccccc}
\hline Variable Relation & Mediation Variable & Coefficient & Deviation Standard & t- Statistics & P- Value \\
\hline $\mathrm{X} 1 \rightarrow \mathrm{Y} 1$ & $\mathrm{X} 2$ & 0,268 & 0,131 & 2,045 & 0,041 \\
\hline
\end{tabular}

Source: Research Result.

Note: $X 1$ = Tourism development; $X 2$ = Inclusiveness economic growth; $X 3=$ Structural economic change.

\section{DISCUSSION OF RESULTS}

Statistically the development of tourism has a positive and significant effect on inclusive economic growth in the Province of Bali. The development of tourism in this study uses indicators of the number of foreign and domestic tourists, as well as the added value of the hotel and restaurant trade sector. On the other hand, indicators of inclusive economic growth are the rate of economic growth, employment, and the level of poverty. With the development of the tourism sector in the province of Bali led to inclusive economic growth or economic growth of quality which is also followed by a decrease in unemployment and poverty, although there is an increasing income inequality between income earners.

This finding is in accordance with Cohen (1984) saying that tourism has an impact on local communities. The results of this study are in accordance with Ave (2006) that the development of tourism in addition to causing increased income also increases increased employment opportunities, both directly in the tourism sector such as hotels, restaurants, travel agencies, and tour guides (guides) as well as other sectors that provide input to the sector supporting tourism, such as the agricultural sector in a broad sense, the industrial sector and other services sectors.

This study is in accordance with the United Nations report United Nation (2017) entitled: "Tourism for Transformation and Inclusive Growth", in the Economic Development in Africa 2017 report. This study statistically concludes that tourism development has a positive effect on changes in economic structure. This finding is consistent with the perspective of developmentalist views put forward Pey and Lin (1983) and Nugroho (1997) which says that aside from being a source of foreign exchange earnings, the tourism industry has many elements that can "encourage" economic change, from traditional agriculture to modern industrial societies. This study is in accordance with the opinion expressed by Pizam and 
Milman cited by Pitana (2005) that tourism has an impact on changes in livelihoods / jobs and people's consumption patterns. The results of this study are consistent with research conducted Batta (2014) which concludes that the rapidly developing tourism industry in Nepal causes income in this sector to develop more rapidly than in the agricultural sector, causing changes in economic structure.

Statistically this study concludes that inclusive economic growth influences the economic structure in the Province of Bali. This means that the inclusive economic growth causes a change in economic structure. The shift in the economic structure in the Province of Bali during 1981 - 2018 was caused by the rapid development of the tourism sector. The results of this study are in accordance with Kuznet's opinion as quoted by Chenery and Syrquin (1988) and Tambunan (2001) that in terms of demand changes in economic structure are caused by economic growth which subsequently leads to increased income per capita or people's purchasing power. In addition to increasing demand for existing goods, it also enlarges the market for new non-food goods.

This study concludes statistically the development of tourism has an indirect effect on economic structure through inclusive economic growth. That is, the development of the tourism sector causes an inclusive economic growth, and with the inclusion of economic growth causes a change in economic structure. This is consistent with the theory or opinion put forward by Spillane (1989), Lundberg et al (1997) and also Ave (2006) that the tourism industry is a very long chain, so that its effects cannot be seen only directly, but also must be indirectly.

\section{CONCLUSION}

Based on the results and discussion, some conclusions can be drawn as follows. The development of tourism has a positive effect on inclusive economic growth and economic structure in the Province of Bali. The development of tourism also resulted in changes in the economic structure, namely the increased contribution of the non-agricultural sector in creating added value and absorbing labor, as well as an increasing percentage of household expenditure for non-food. Inclusive economic growth has a positive effect on the economic structure in the Province of Bali. The indirect influence of the development of tourism on the economic structure through inclusive economic growth and in the Province of Bali. This can be explained that with the development of tourism causes an inclusive economic growth, further inclusive economic growth causes changes in economic structure.

\section{REFERENCES}

1. APEC. 2016. "Tourism Arrival and Inclusive Growth". Paper No. 11. Singapore: AsiaPacific Economic Cooperation Tourism Working Group.

2. Archer, B. H. 2000. "Tourism and Island Economies: Impact Analysis", dalam: Clem Tisdell, The Economics of Tourism, Volume II, An Elgar Reference Collection, Cheltenham, UK Nothhampton, USA.

3. Ave, Joop. 2006. "Peran Strategis Sektor Pariwisata dalam Pembangunan Ekonomi Nasional". Makalah disampaikan pada acara Seminar and Diskusi terfokus ISEI: Sektor Jasa sebagai Motor Penggerak Ekonomi Daerah, 18 Mei 2006, Denpasar.

4. Batta, Guna Raj. 2014. Structural Chane in a Small and Open Economy: Evidennces from Nepal. NRB Working Paper No.23. Nepal: Nepal Rastra Bank.

5. Birdsall, Nancy. 2007. Reflections on the Macro Foundations of the Middle Class in theDeveloping World. Center for Global Development Working Paper 130, Washington DC.

6. Bull, Andrian. 1991. The Economics of Travel and Tourism. Melbourne: Longman Cheshire Pty Limited.

7. Chenery, H.B., and M. Syrquin. 1975. Patterns of Development 1950-1970. London: Oxford University Press. 
8. Chin, W. W. 1998. The Partial Least Squares Aproach to Structural Equation Modeling. Modern Methods for Business Research, 295, 336

9. Clarke, Mattew and Sardar M.N. Islam. 2004. "Health Adjusted GDP (HAGDP) Measures of the Relationship Between Economic Growth, Health Outcomes and Social Walfare". CESifo Working Paper Series No. 1002.

10. Cohen, Erik. 1984. "The Sosiology of Tourism: Approach, Issues and Finding". Annal of Tourism Reserch 30: pp 336--66.

11. Ghozali, Imam. 2011. Structural Equetion Model dengan alternatif Partial Least Square (PLS). Semarang: Badan Penerbit Universitas Diponegoro.

12. Inskeep, Edward. 1991. Tourism Planning, Integrated and Sustainable Development Approach. New York: Van Nostrand Reinhold.

13. Lundberg, Donald R, Mink H. Stavenga and M. Krishnamoorthy. 1997. Ekonomi Pariwisata (Alih bahasa: Sofyan Yusuf). Jakarta: PT. Gramedia Pustaka Utama.

14. Martin, Juan Luis Eugenio, Noelia Martin Morales and Riccardo Scarpa. 2004. "Tourism and Economic Growth in Latin American Countries: A Panel Data Approach". Sosial Science Research Network Electronic Paper Collection.

15. Nowak, Jean-Jaques, and Monder Sahli. 2004. "Tourism, Trade and Domestik Welfare". FEEM Working Paper 24. Sosial Science Research Network Electronic Paper Collection.

16. Nugroho, Heru. 1997. "Industrialisasi Sektor Pariwisata: Pintu Masuk Pembangunan atau Pelembagaan Keterbelakangan" dalam majalah Kelola, dipublikasikan oleh Program Studi Magister Manajemen Universitas Gadjah Mada, Yogyakarta, No. 16/VI/1997, halaman 28--39.

17. Pitana, I Gede. 2005. Sosiologi Pariwisata. Yogyakarta: Andi.

18. Pye, Elwood A. and Tzong-Biau Lin. 1983. Tourism in Asia, The Economic Impact, Singapura: Singapore University Press.

19. Spillane, James, J. 1989. Ekonomi Pariwisata, Sejarah and Prospeknya. Yogyakarta: Kanisius.

20. Syrquin, Moshe. 1988. "Pattern of Structural Change", pp. 203--273 (dalam Hollis B. Chenery and T.N. Srinivasan (ed). Handbook of Development Economics Vol. I, Amsterdam: Elsevier Science Publishers B.V.

21. Tambunan, Tulus.TH, 2001. Transformasi Ekonomi di Indonesia: Teori \& Penemuan Emperis, Jakarta: Salemba Empat.

22. Todaro, Michael P. 2000. Pembangunan Ekonomi di Dunia Ketiga, Buku 1 Edisi Ketujuh. Jakarta: Penerbit Erlangga.

23. United Nation. 2017. Tourism for Transformative and Inclusive Growth. In Economic Development in Africa Report 2017. New York and Geneva: United Nation. 